\title{
STUDY OF OXYGEN CHEMISORPTION DURING REGENERATION OF QUINHYDRONE ABSORBING SOLUTION IN THE APPARATUS WITH A CONTINUOUS BUBBLING LAYER
}

\author{
Andriy Slyuzar ${ }^{1,}{ }^{凶}$, Zenoviy Znak ${ }^{1}$, Yaroslaw Kalymon ${ }^{1}$, Andriy Helesh ${ }^{1}$
}

https://doi.org/10.23939/chcht14.02.257

\begin{abstract}
The enhancement factor of air oxygen absorption by quinhydrone absorbing solution in the apparatus with a continuous bubbling layer and the rate constant for the reaction of chemisorbed oxygen and the reducing form of quinhydrone oligomers have been determined. The obtained results are of practical importance for the choice of mass-transfer apparatus for the regeneration of quinhydrone absorbing solution when removing hydrogen sulfide from gases.
\end{abstract}

Keywords: oxygen chemisorption, absorbing solution, regeneration, quinhydrone, oligomers, bubbling layer.

\section{Introduction}

As a result of natural chemical and biological processes during the industrial processing of mineral and organic raw materials, sulfurous compounds contained in raw materials are more often converted into hydrogen sulfide, which accumulates in gas or liquid phases. Due to the high toxicity of hydrogen sulfide, its removal from gases is vitally needed. Moreover, the removed hydrogen sulfide may be used for the production of sulfur or sulfuric acid $[1,2]$.

Liquid-phase oxidative methods (Lo-Cat, Stretford, Takahaks, Thylox, Unisulf, etc.) are of significant practical interest for the purification of oxygen-free sulfurcontaining gases (natural, petroleum, coke, etc.) [3-7]. The quinhydrone method of hydrogen sulfide removal, developed at Lviv Polytechnic National University, can compete with the best world analogs $[1,2,8]$.

This method is based on the chemisorption of hydrogen sulfide from gas by soda solution of quinhydrone ( $1^{\text {st }}$ stage):

$$
\mathrm{H}_{2} \mathrm{~S}+\mathrm{Na}_{2} \mathrm{CO}_{3} \Leftrightarrow \mathrm{NaHS}+\mathrm{NaHCO}_{3}
$$

At the $2^{\text {nd }}$ stage of the process, the chemisorbed hydrogen sulfide is oxidized to sulfur by quinhydrone, and

\footnotetext{
${ }^{1}$ Lviv Polytechnic National University,

12, S. Bandera St., 79013 Lviv, Ukraine

savasl2000@yahoo.com

(c) Slyuzar A., Znak Z., Kalymon Ya., Helesh A., 2020
}

at the $3^{\text {rd }}$ stage quinhydrone is regenerated by air oxygen. Actually, not quinhydrone but products of its oligomerization existed in both the oxidation (quinone) and reducing (hydroquinone) forms, participate in the process. The molecular weight of these oligomers varies from 300 to 800 (average value is 400) [2], whereas for quinhydrone it is $218 \mathrm{~g} / \mathrm{mol}$. Therefore, the $2^{\text {nd }}$ and $3^{\text {rd }}$ stages can be described by the following equations:
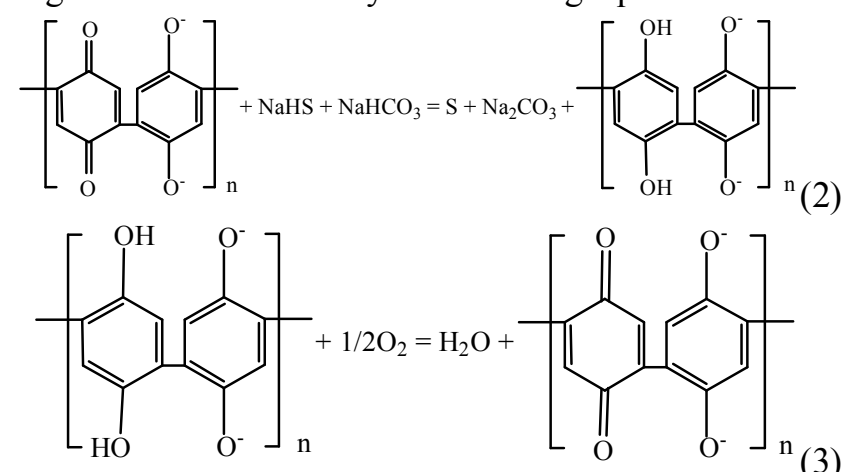

where $n$ is the number of oligomer fragments, $n=1-4$.

Flow chart of hydrogen sulfide removal from oxygen-free gases by quinhydrone method should include two main apparatuses: absorber and regenerator. Eq. (1) and partially Eq. (2) proceed in the absorber; Eqs. (2) and (3) - in the regenerator. The calculations carried out according to Eqs. (1) and (2) show that in the absorbing solution containing $10-20 \mathrm{~kg} / \mathrm{m}^{3}$ of $\mathrm{Na}_{2} \mathrm{CO}_{3}$ and $5 \mathrm{~kg} / \mathrm{m}^{3}$ of quinhydrone the equivalent concentration of chemisorbed hydrogen sulfide is 7-14 times higher than the equivalent concentration of quinhydrone oligomers. It means that the degree of oxidation of chemisorbed hydrogen sulfide in the absorber does not exceed $7.5-15 \%$ and the solution containing a reducing form of quinhydrone oligomers and the main part (85-92.5\%) of chemisorbed hydrogen sulfide is directed to the regenerator.

Two main processes take place in the regenerator: the absorption of air oxygen by quinhydrone absorbing solution and the oxidation of the oligomers reducing form with absorbed oxygen, i.e., the oxygen chemisorption occurs. The most rational mass-transfer apparatus for the chemisorption process is an apparatus where the rates of 
abovementioned processes are commensurable [7, 9, 10]. For the removal of hydrogen sulfide by quinhydrone method a proven horizontal absorber with bucket-like dispersers was used [11]. However, in most industrial liquid-phase oxidative processes for the regeneration of absorbing solutions, absorbers with a continuous bubbling layer are usually used [3]. The effectiveness of this type of apparatus for the quinhydrone method is unknown. Therefore, there is a need for conducting studies of oxygen chemisorption by a quinhydrone absorbing solution in this type of mass-transfer apparatus.

The purpose of the research was to determine the enhancement factor of oxygen absorption by quinhydrone absorbing solution in the apparatus with a continuous bubbling layer, as well as the rate constant for the reaction of dissolved oxygen and quinhydrone oligomers. It was also necessary to study the rate of oxygen absorption by the absorbing solution without quinhydrone oligomers (soda solution) and the rate of oxygen chemisorption by quinhydrone solution saturated with hydrogen sulfide at different air flow rates.

\section{Experimental}

\subsection{Materials}

Soda solution $\left(10 \mathrm{~kg} / \mathrm{m}^{3} \mathrm{Na}_{2} \mathrm{CO}_{3}\right)$ was obtained by dissolving soda in distilled water. Before the experiments it was boiled for degassing from dissolved oxygen, and then cooled in the absence of air to a given temperature.

Quinhydrone solution was obtained from a solution of oligomerized quinhydrone $[2,8]$. For this purpose, quinhydrone - the molecular complex of quinone and hydroquinone $\mathrm{C}_{6} \mathrm{H}_{4} \mathrm{O}_{2} \cdot \mathrm{C}_{6} \mathrm{H}_{6} \mathrm{O}_{2}$ was dissolved in the soda solution, providing the ratio of soda:quinhydrone $=2: 1$ $\left(\mathrm{mol} / \mathrm{dm}^{3}\right)$. This solution was kept for 7 days with air access under periodic stirring. The oxidation-reducing properties of the resulting solution of quinhydrone oligomers were controlled by the cyclic voltammetry method [8]. The resulting product was used to obtain a quinhydrone solution with concentrations of $10 \mathrm{~kg} / \mathrm{m}^{3}$ of $\mathrm{Na}_{2} \mathrm{CO}_{3}$ and $5 \mathrm{~kg} / \mathrm{m}^{3}$ of quinhydrone. Before the experiments the quinhydrone solution was saturated with hydrogen sulfide. For this purpose, a mixture of natural gas and hydrogen sulfide was bubbling through a solution to achieve the hydrogen sulfide concentration of $0.85 \mathrm{~kg} / \mathrm{m}^{3}$. Hydrogen sulfide was obtained by decomposition of sodium sulfide solution with $20 \%$ solution of sulfuric acid.

All reagents were of chemically pure grade.

\subsection{Methods}

The experiments were carried out at the laboratory setup, the main apparatus of which was a hollow glass column with an internal diameter of $0.035 \mathrm{~m}$ and height of $0.5 \mathrm{~m}$. At the bottom of the column a bubbler was mounted, through which the air or the mixture of natural gas with hydrogen sulfide were supplied. The bubbler was made in the form of a porous glass plate with the thickness of $\sim 5 \mathrm{~mm}$ and pore size of $0.2-0.6 \mathrm{~mm}$.

In the first series of experiments the effect of air flow rate (solution gas content) on the rate of oxygen absorption by soda solution was studied. The experiments were carried out at the following constant parameters: temperature $290 \mathrm{~K}$, solution height in a column $0.25 \mathrm{~m}$, solution volume $2.4 \cdot 10^{-4} \mathrm{~m}^{3}$, absorption time $480 \mathrm{~s}$. The air flow rate was $(0.78-1.83) \cdot 10^{-6} \mathrm{~nm}^{3} / \mathrm{s}$, which was controlled by the rheometer. The dissolved oxygen content was determined before and after the experiments using Winkler method and the EZODO 7031 oxygen meter.

In the second series of experiments the effect of air flow on the rate of oxygen chemisorption by quinhydrone absorbing solution was studied. The research parameters were the same as those in the first series, which made it possible to provide the same contact surface of phases and compare the processes. The oxygen chemisorption time was increased to $1800 \mathrm{~s}$. The dissolved hydrogen sulfide content was determined before and after the experiments. For this purpose, the sample solution was placed in a flask, acidified with $\mathrm{HCl}$ solution to $\mathrm{pH}=2.5-3$, and nitrogen was bubbled through it. The content of hydrogen sulfide in the recovered nitrogen-hydrogen sulfide mixture was determined by iodometric method using a solution of cadmium acetate as a hydrogen sulfide absorber, and then converted to its concentration in solution.

\subsection{Calculation Methods and Processing of Experimental Results}

The description of oxygen chemisorption process by quinhydrone absorbing solution saturated with hydrogen sulfide requires the solution of the equations of dissolved oxygen and quinhydrone oligomers diffusion transfer, as well as the chemical kinetics of the reaction (3). For the analytical solution of such equations the simplified models are used, which are based on assumptions regarding the medium movement, the geometric form of the interphase surface, etc. To describe the oxygen chemisorption by the absorbing solution, we chose a two-film model, which is more illustrative and based on a simpler mathematical model [9].

To calculate the absorption enhancement factor $\chi$ the values of liquid-side mass-transfer coefficients in the chemisorption $\left(\beta_{L}{ }^{c h e m}\right)$ and absorption $\left(\beta_{L}{ }^{a b s}\right)$ processes are used. Both liquid-side and gas-side mass-transfer coefficients are related to the gas sorption rate according to the basic mass-transfer equation [9]: 


$$
\frac{d N_{O_{2}}}{d \tau}=\frac{1}{\frac{1}{\beta_{G}{ }^{\prime}}+\frac{m_{p C}}{\beta_{L}}} \cdot F \cdot \Delta P
$$

where $N_{O 2}$ is the amount of absorbed oxygen, mol; $\tau$ is time, $\mathrm{s} ; \beta_{G^{\prime}}$ is a gas-side mass-transfer coefficient, $\mathrm{mol} /\left(\mathrm{m}^{2} \cdot \mathrm{s} \cdot \mathrm{Pa}\right) ; \beta_{L}$ is a liquid-side mass-transfer coefficient, $\mathrm{m} / \mathrm{s} ; m_{p C}$ is the constant of the phase equilibrium, $\mathrm{m}^{3} \cdot \mathrm{Pa} / \mathrm{mol} ; 1 / \beta_{G}{ }^{\prime}$ and $m_{p C} / \beta_{L}$ are gas-side and liquid side mass-transfer resistance, respectively, $\mathrm{m}^{2} \cdot \mathrm{s} \cdot \mathrm{Pa} / \mathrm{mol} ; \Delta P$ is a driving force of the process, $\mathrm{Pa} ; F$ is the surface of masstransfer, $\mathrm{m}^{2}$.

In order to estimate the ratio of gas-side and liquid side mass-transfer resistances (Eq. (4)), we theoretically calculated corresponding mass-transfer coefficients. In order to calculate the gas-side mass-transfer coefficient during the absorption from a single bubble, the following equations are proposed [9]:

$$
\begin{aligned}
S h_{G}=\frac{\beta_{G} \cdot d_{b}}{D_{G}} & =\frac{1}{6 F o_{G}{ }^{\prime}}\left[1-\frac{6}{\pi^{2}} \exp \left(-4 \pi^{2} \cdot F o_{G}{ }^{\prime}\right)\right] \\
D_{G} & =D_{273} \cdot\left(\frac{T}{273}\right)^{1.75} \\
F o_{G}{ }^{\prime} & =\frac{D_{G} \cdot \tau}{d_{b}^{2}}=\frac{D_{G}}{w_{b} \cdot d_{b}} \\
\tau & =\frac{d_{b}}{w_{b}} \\
w_{b} & =1.5\left(\frac{\sigma \cdot g \cdot \Delta \rho}{\rho_{L}^{2}}\right)^{0.25}
\end{aligned}
$$

where $S h_{G}$ is the Sherwood number for the gas phase; $F_{O_{G}}{ }^{\prime}$ is the Fourier number for the gas phase; $d_{b}$ is a bubble diameter, $\mathrm{m} ; D_{G}$ is the coefficient of oxygen molecular diffusion in the air at the experimental temperature, $\mathrm{m}^{2} / \mathrm{s}$; $D_{273}$ is the coefficient of oxygen molecular diffusion in the air (273 K and $0.1 \mathrm{MPa})$ equal to $0.178 \cdot 10^{-4} \mathrm{~m}^{2} / \mathrm{s}$ [9]; $\tau$ is a contact time, $\mathrm{s} ; w_{b}$ is the bubble floating-up rate, $\mathrm{m} / \mathrm{s}$; $\sigma$ is a surface tension of water at the boundary with air, $\mathrm{N} / \mathrm{m} ; g$ is an enhancement of gravity, $\mathrm{m}^{2} / \mathrm{s} ; \Delta \rho=\rho_{L}-\rho_{G}$; $\rho_{L}$ and $\rho_{G}$ are water and air density, respectively, $\mathrm{kg} / \mathrm{m}^{3}$.

To calculate the liquid-side mass-transfer coefficient $\left(\beta_{L}, \mathrm{~m} / \mathrm{s}\right)$, the following equations are proposed:

$$
\begin{gathered}
S h_{L}=\frac{\beta_{L} \cdot d_{b}}{D_{L}}=\frac{1.13}{\sqrt{F O_{L}{ }^{\prime}}} \\
D_{L}=\frac{14 \cdot 10^{-9}}{V_{\mathrm{O}_{2}}^{0.6} \cdot \mu_{\mathrm{H}_{2} \mathrm{O}}^{1.1}}
\end{gathered}
$$

where $S h_{G}$ is the Sherwood number for the liquid phase; $F_{O_{G}}{ }^{\prime}$ is the Fourier number for the liquid phase (calculated analogously to Eq. (7) for the gas phase); $D_{L}$ is the coefficient of oxygen molecular diffusion in water, $\mathrm{m}^{2} / \mathrm{s}$; $V_{\mathrm{O} 2}$ is a molar volume of oxygen in a liquid state at a normal boiling point, $V_{\mathrm{O} 2}=25.6 \mathrm{~cm}^{3} / \mathrm{mol} ; \mu_{\mathrm{H}_{2} \mathrm{O}}^{1.1}$ is a dynamic viscosity of water, $\mathrm{mPa} \cdot \mathrm{s}$.

The solution gas content ( $V$, parts of unity) was calculated according to Eq. (12):

$$
V=\frac{n \cdot \pi \cdot d_{b}^{3}}{6 V_{L}}
$$

where $n$ is a number of air bubbles in the solution; $V_{L}$ is a solution volume, $\mathrm{m}^{3}$.

The obtained values were recalculated according to Eqs. (13) and (14) [9]:

$$
\begin{gathered}
\beta_{G}{ }^{\prime}=\frac{\beta_{G}}{R T} \\
m_{p C}=m_{p x} \frac{M_{L}}{\rho_{L}}
\end{gathered}
$$

where $R$ is the absolute gas constant, $R=8.31 \mathrm{~J} /(\mathrm{mol} \cdot \mathrm{K})$; $T$ is temperature, $\mathrm{K} ; m_{p x}$ is the phase equilibrium constant, $m_{p x}=37900 \cdot 10^{2} \mathrm{kPa}$ [9]; $M_{L}$ is solution molar mass, $\mathrm{kg} / \mathrm{kmol} ; \rho_{L}$ is solution density, $\mathrm{kg} / \mathrm{m}^{3}$.

According to the results shown in [12], as well as our theoretical calculations (see below) by Eqs. (5)-(14), the liquid phase creates a main resistance to the oxygen absorption. In this case, the rate of oxygen mass transfer from the gas to liquid phase is determined by the liquidside mass-transfer coefficient; the gas phase resistance $1 / \beta_{G}^{\prime}$ in Eq. (4) can be neglected.

$$
\frac{d N_{O_{2}}}{d \tau}=\frac{\beta_{L}}{m_{p C}} \cdot F \cdot \Delta P
$$

The driving force of oxygen absorption by soda solution at the inlet of the column $\left(\Delta P_{i n}{ }^{a b s}\right)$ was calculated as the difference between the partial pressure of oxygen in the air and the average equilibrium oxygen pressure over the solution during the experiment. The driving force of oxygen absorption at the outlet of the column $\left(\Delta P_{\text {out }}^{a b s}\right)$ was calculated as the difference between the partial pressure of oxygen in the air after the column and the average equilibrium partial pressure of oxygen over the solution during the experiment. The average equilibrium partial pressure of oxygen in the air above the solution was taken as that for water. The partial pressure of oxygen in the air at the outlet of the column was calculated as the difference between the partial pressure of oxygen in the air and the partial pressure, which was reduced due to the oxygen absorption.

Oxygen is absent in the quinhydrone solution containing hydrogen sulfide (within the studied concentrations). Therefore, the driving force of oxygen chemisorption by a quinhydrone solution at the column inlet $\left(\Delta P_{i n}^{\text {chem }}\right)$ is equal to the partial pressure of oxygen in the air, and the driving force at the column outlet $\left(\Delta P_{\text {out }}^{\text {chem }}\right)$ is the difference between the partial pressure of oxygen in the air and the partial pressure, which was 
reduced due to the oxygen chemisorption. The average driving force of absorption $\left(\Delta P^{a b s}\right)$ or chemisorption $\left(\Delta P^{\text {chem }}\right)$ was defined as the arithmetic mean of the driving forces at the inlet and outlet, since these values differ by no more than 1.2 times.

The amount of chemisorbed oxygen was calculated from the number of oxidized chemisorbed hydrogen sulfide.

We investigated the absorption and chemisorption of oxygen by sodium and quinhydrone solutions respectively, under bubble-jet mode, which made it impossible to accurately determine the size and number of the bubbles and, hence, the contact surface of the phases. Therefore, the experiments were carried out with the same contact surface of the phases both for absorption and chemisorption processes (the same apparatus, air flow rate, temperature, volume of solutions, soda concentration, etc.). According to the experimental results the product of the liquid-side masstransfer coefficients and the contact surface of the phases $\left(F_{i}\right)$ was determined. The ratio of products shows the value of absorption enhancement factor $\chi$ [9]:

$$
\chi=\frac{\beta_{L}^{\text {chem }} \cdot F_{i}}{\beta_{L}^{a b s} \cdot F_{i}}=\frac{\beta_{L}^{\text {chem }}}{\beta_{L}^{\text {abs }}}
$$

The absorption enhancement factor depends on the parameters $R$ and $M$ [9]. In terms of the two-film model, these parameters for our system have the following physical meaning: $R$ is the ratio of the reaction rate in the film to the rate of oxygen diffusion through the liquid film; $M$ is the ratio of the diffusion rates through the liquid film of the recovered form of quinhydrone oligomers and oxygen.

In the apparatus with a continuous bubbling layer the reaction rate of dissolved oxygen and reducing form of quinhydrone oligomers is significantly higher than the rate of oxygen absorption. For chemisorption processes, where $\chi \geq 5$, the reaction occurs in the liquid film, i.e. the concentration of the absorbed substance is equal to zero. According to [9], for the rapid reaction occurring in the film, the enhancement factor $\chi$ and the parameters $R$ and $M$ are related by Eqs. (17)-(19).

$$
\begin{gathered}
\chi=\frac{2(M+1)}{1+\sqrt{1+4\left(\frac{M}{R}\right)^{2}}} \\
M=\frac{C_{2}}{g \cdot C_{1}^{*}} \cdot \frac{D_{2}}{D_{1}} \\
R=\frac{1}{\beta_{L}} \sqrt{\frac{2}{m+1} \cdot D_{1} \cdot k_{1} \cdot C_{1}^{* m-1} \cdot C_{2}}
\end{gathered}
$$

where $C_{1}{ }^{*}$ is the concentration of oxygen at the interface between the gas and liquid phases (it is taken equal to the concentration of saturation), $\mathrm{mol} / \mathrm{m}^{3} ; C_{2}$ is the concen- tration of oligomers reducing form in the solution flow core, $\mathrm{mol} / \mathrm{m}^{3} ; g$ is the number of hydroquinone groups of oligomer reacted with oxygen according to Eq. (3); $D_{1}$ and $D_{2}$ are the diffusion coefficients of oxygen and the reducing form of quinhydrone oligomers in a solution, respectively, $\mathrm{m}^{2} / \mathrm{s} ; k_{1}$ is the reaction rate constant; $m$ and $n$ are the reaction order with respect to the corresponding concentrations.

Eq. (19) allows to calculate the rate constant $k_{1}$ for the reaction of dissolved oxygen and the reducing form of the quinhydrone oligomers.

\section{Results and Discussion}

The results calculated according to Eqs. (5)-(14) are given in Table 1. As it was expected, during air oxygen absorption by soda solution in the apparatus with a continuous bubbling layer, at low gas content the liquidside mass-transfer resistance is by $(1.9-2.7) \cdot 10^{3}$ times greater than the resistance of the gas phase. With a decrease in the bubbles diameter the gas-side and liquidside mass-transfer coefficients are increased. However, the increase in $\beta_{L}$ value is sharper. Thus, with the decrease in the bubbles diameter from 0.006 to $0.002 \mathrm{~m}$ the value of $\beta_{G}$ increases by 1.37 times, and $\beta_{L}-$ by 1.73 times.

The experimental results and calculations according to Eq. (15) are presented in Table 2. One can see that with increasing air flow rate the product of the liquid-side mass-transfer coefficient and the bubbles surface slightly increase. For example, with the 2 time increase in air flow rate (from $0.78 \cdot 10^{-6}$ to $1.56 \cdot 10^{-6} \mathrm{~m}^{3} / \mathrm{s}$ ), the product $\beta_{L}{ }^{a b s} F_{i}$ increases from $2.285 \cdot 10^{-7}$ to $2.815 \cdot 10^{-7}(\mathrm{~m} / \mathrm{s}) \cdot \mathrm{m}^{2}$, i.e., only by 1.23 times. This is obviously due to the fact that the increase in air flow rate (gas content) increases the masstransfer surface, and simultaneously contributes to the coalescence of the bubbles, which reduces the actual mass-transfer surface.

An important index of the absorption process is the absorption degree and the amount of absorbed oxygen (Table 2). The degree of oxygen absorption is low (less than $0.8 \%$ ) and increases with the decrease in air flow rate (gas content). Thus, for air flow rates of $0.78 \cdot 10^{-6}$ and $1.56 \cdot 10^{-6} \mathrm{~m}^{3} / \mathrm{s}$, the absorption degree is 0.790 and $0.471 \%$, respectively. The low degree of oxygen absorption is evidently due to the high liquid-side mass-transfer resistance and small height of the bubbling $(0.25 \mathrm{~m})$, and, as it was mentioned above, the bubbles coalescence takes place with the increase in gas content. The amount of absorbed oxygen increases slightly with increasing air flow rate. 
Table 1

The results calculated according to the criterial equations of mass transfer*

\begin{tabular}{|c|c|c|c|c|c|c|c|}
\hline \multirow{2}{*}{$\begin{array}{l}\text { Bubbles } \\
\text { diameter } \\
d_{b} \cdot 10^{3}, \mathrm{~m}\end{array}$} & \multirow{2}{*}{$\begin{array}{c}\text { Number } \\
\text { of bubbles } \\
n\end{array}$} & \multirow{2}{*}{$\begin{array}{c}\text { Gas } \\
\text { content } V \text {, } \\
\text { parts of } \\
\text { unity }\end{array}$} & \multicolumn{2}{|c|}{$\begin{array}{l}\text { Gas-side mass-transfer } \\
\text { coefficients }\end{array}$} & \multirow{2}{*}{$\begin{array}{l}\text { Liquid-side } \\
\text { mass-transfer } \\
\text { coefficient } \\
\beta_{L} \cdot 10^{4}, \mathrm{~m} / \mathrm{s}\end{array}$} & \multirow{2}{*}{$\begin{array}{c}\text { Gas-side mass- } \\
\text { transfer } \\
\text { resistance } \\
\left(1 / \beta_{G}\right) \cdot 10^{-5} \\
\mathrm{~m}^{2} \cdot \mathrm{s} \cdot \mathrm{Pa} / \mathrm{mol}\end{array}$} & \multirow{2}{*}{$\begin{array}{c}\text { Liquid-side mass- } \\
\text { transfer } \\
\qquad\left(m_{p C} / \beta_{L}\right) \cdot 10^{-8} \\
\mathrm{~m}^{2} \cdot \mathrm{s} \cdot \mathrm{Pa} / \mathrm{mol}\end{array}$} \\
\hline & & & $\begin{array}{c}\beta_{G} \cdot 10^{2}, \\
\mathrm{~m} / \mathrm{s}\end{array}$ & $\begin{array}{c}\beta_{G}^{\prime} \cdot 10^{5}, \\
\mathrm{~mol} /\left(\mathrm{m}^{2} \cdot \mathrm{s} \cdot \mathrm{Pa}\right)\end{array}$ & & & \\
\hline \multirow{3}{*}{2} & 5 & $1.75 \cdot 10^{-5}$ & \multirow{3}{*}{3.586} & \multirow{3}{*}{1.488} & \multirow{3}{*}{5.365} & \multirow{3}{*}{0.672} & \multirow{3}{*}{1.269} \\
\hline & 15 & $5.23 \cdot 10^{-5}$ & & & & & \\
\hline & 50 & $1.75 \cdot 10^{-4}$ & & & & & \\
\hline \multirow{3}{*}{4} & 5 & $1.39 \cdot 10^{-4}$ & \multirow{3}{*}{2.966} & \multirow{3}{*}{1.231} & \multirow{3}{*}{3.794} & \multirow{3}{*}{0.812} & \multirow{3}{*}{1.795} \\
\hline & 15 & $4.19 \cdot 10^{-4}$ & & & & & \\
\hline & 50 & $1.39 \cdot 10^{-3}$ & & & & & \\
\hline \multirow{3}{*}{6} & 5 & $4.71 \cdot 10^{-4}$ & \multirow{3}{*}{2.624} & \multirow{3}{*}{1.089} & \multirow{3}{*}{3.097} & \multirow{3}{*}{0.918} & \multirow{3}{*}{2.199} \\
\hline & 15 & $1.41 \cdot 10^{-3}$ & & & & & \\
\hline & 50 & $4.71 \cdot 10^{-3}$ & & & & & \\
\hline \multirow{3}{*}{10} & 5 & $2.18 \cdot 10^{-3}$ & \multirow{3}{*}{2.278} & \multirow{3}{*}{0.945} & \multirow{3}{*}{2.399} & \multirow{3}{*}{1.058} & \multirow{3}{*}{2.838} \\
\hline & 15 & $0.65 \cdot 10^{-2}$ & & & & & \\
\hline & 50 & $2.18 \cdot 10^{-2}$ & & & & & \\
\hline
\end{tabular}

*Calculations are made for such constant parameters: temperature $290 \mathrm{~K}$; solution concentration $10 \mathrm{~kg} / \mathrm{m}^{3} \mathrm{Na}_{2} \mathrm{CO}_{3}$.

The experimental results and calculations of air oxygen chemisorption by quinhydrone absorbing solution show (Table 3) that the product of the liquid-side masstransfer coefficient and the bubbles surface increases slightly with increasing air flow rate, the same as for the absorption process. For example, with the increase in air flow rate by more than 2 times (from $0.78 \cdot 10^{-6}$ to $1.83 \cdot 10^{-6} \mathrm{~m}^{3} / \mathrm{s}$ ), the product $\beta_{L}{ }^{\text {chem. }} F_{i}$ increases by only 1.19 times. The rest of the chemisorption parameters (the amount of chemisorbed oxygen per unit time, the chemisorption degree, the driving force of the process, the amount of chemisorbed oxygen) are changing similar to the corresponding parameters of absorption. However, there is a big difference between the absolute values of these processes. Thus, at the same air flow rate (the same gas content, the size and surface of the bubbles), the degree of oxygen chemisorption is higher by 5.7-6.6 times in comparison with the absorption process. The values of chemisorbed oxygen amount per time unit and chemisorption driving force are also higher. The liquidside mass-transfer coefficient is $\beta_{L}^{\text {chem }}=1.04 \cdot 10^{-4} \mathrm{~m} / \mathrm{s}$.

The main result of oxygen absorption (Table 2 ) and chemisorption (Table 3) studies in the apparatus with a continuous bubbling layer is the determination of the absorption enhancement factor, the average value of which is 5.14.

Calculations of the parameters $M$ and $R$ by Eqs. (18) and (17), respectively, show that $M=9.95$ and $R=6.42$. For calculations by Eq. (18) the following values were taken: $D_{1}=1.8 \cdot 10^{-9} \mathrm{~m}^{2} / \mathrm{s} ; C_{2}=12.5 \mathrm{~mol} / \mathrm{m}^{3}$; $C_{1}{ }^{*}=0.307 \mathrm{~mol} / \mathrm{m}^{3} ; g=2$. In literature sources there are no data regarding the diffusion coefficients of quinhydrone oligomers in water, so we used the diffusion coefficient of sucrose $\mathrm{C}_{12} \mathrm{H}_{21} \mathrm{O}_{4}$ - a substance which is close to them with respect to solubility and molecular weight, $D_{2}=0.88 \cdot 10^{-9} \mathrm{~m}^{2} / \mathrm{s}$ [9]. The obtained values of $M>R>\chi$ indicate that the reaction between the dissolved oxygen and the reducing form of oligomers has a high rate and ends in the liquid film. The partial oxygen pressure over the quinhydrone solution containing chemisorbed hydrogen sulfide is equal to zero [9].

To calculate the rate constant using Eq. (19), we adopt $m=1$ and $n=1$, which is characteristic of similar chemisorption processes [9]. By comparing the values of oxygen concentration $C_{1}{ }^{*}$ and quinhydrone oligomers concentration $C_{2}$, it can be assumed that $C_{2}$ is constant and the chemical reaction proceeds by the pseudo first order with the rate constant $k_{2}=k_{1} \cdot C_{2}$. Then Eq. (19) can be written as follows:

$$
R=\frac{1}{\beta_{L}} \sqrt{D_{1} \cdot k_{2}}
$$

The results of calculations are given in Table 4 .

The increase in air flow rate results in the increase of oxygen chemisorption rate. For example, the increase in the air flow rate by 2 times (from $0.78 \cdot 10^{-6}$ to $1.56 \cdot 10^{-6} \mathrm{~m}^{3} / \mathrm{s}$ ) leads to 1.33 time increase in the chemisorption rate (from $1.39 \cdot 10^{-3}$ to $1.85 \cdot 10^{-3} \mathrm{~mol} /\left(\mathrm{m}^{3} \cdot \mathrm{s}\right.$ ).

The reaction rate of chemisorbed oxygen and reducing form of quinhydrone oligomers is much greater than the oxygen chemisorption rate. With increasing air flow rate the ratio of chemical reaction rate to the oxygen chemisorption rate decreases. For the same size of bubbles this ratio does not depend on the air flow rate. This fact again confirms the coalescence of the bubbles with increasing air flow rate. Under bubbling mode of chemisorption, which is observed at air flow rate below $0.78 \cdot 10^{-6} \mathrm{~nm}^{3} / \mathrm{s}$, and the bubbles size of $0.002 \mathrm{~m}$ the ratio $v_{r} / v_{\text {chem }} \geq 427$. This ratio unambiguously indicates that the resistance to oxygen chemisorption is concentrated in a liquid film. 


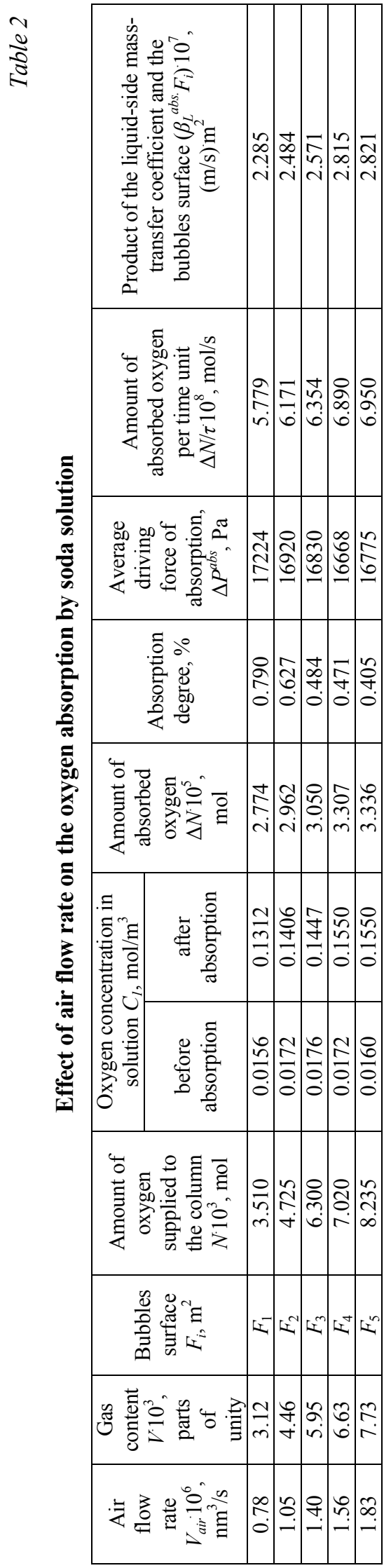

$\frac{n}{2}$

\begin{tabular}{|c|c|c|c|c|c|}
\hline 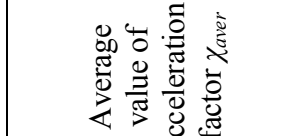 & \multicolumn{5}{|c|}{$\nabla$} \\
\hline 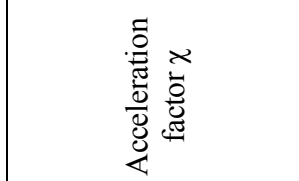 & $\mid \begin{array}{l}\mathscr{\infty} \\
\infty \\
\dot{+}\end{array}$ & $\begin{array}{r}\tilde{r} \\
\dot{\gamma}\end{array}$ & $\begin{array}{c}0 \\
\vdots \\
n \\
n\end{array}$ & $\begin{array}{l}\vec{n} \\
\vec{n}\end{array}$ & \\
\hline 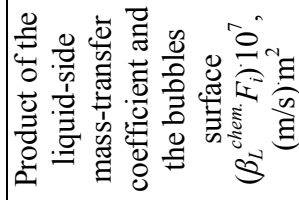 & 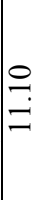 & సે & 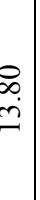 & $\begin{array}{l}: \\
: \\
\dot{ \pm} \\
-\end{array}$ & \\
\hline 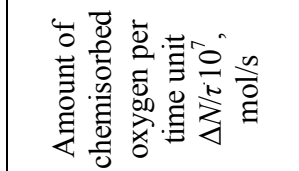 & लिे & & $\frac{6}{+}$ & $\begin{array}{l}\text { J } \\
\forall \\
\forall\end{array}$ & \\
\hline 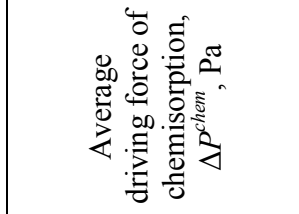 & 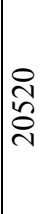 & 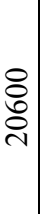 & 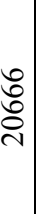 & & \\
\hline 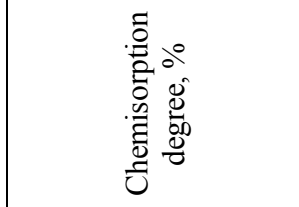 & 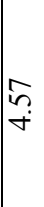 & & & $\underset{\dot{m}}{8}$ & \\
\hline 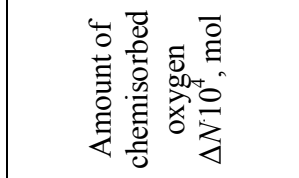 & $\dot{0}$ & & ?ִ & 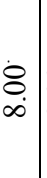 & \\
\hline 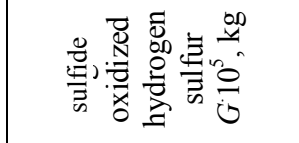 & $\underset{+}{\partial}$ & $\begin{array}{l}\stackrel{+}{r} \\
\stackrel{+}{+}\end{array}$ & & 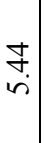 & \\
\hline 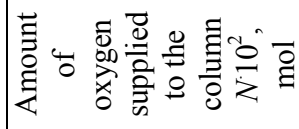 & $\frac{\widetilde{\sigma}}{m}$ & 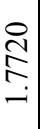 & $\begin{array}{l}\frac{n}{0} \\
\stackrel{n}{i} \\
\end{array}$ & 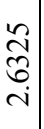 & \\
\hline 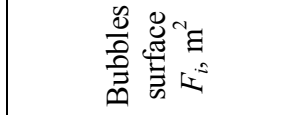 & 10 & $x^{2}$ & $\mathbb{L}^{2}$ & $\mathbb{L}^{+}$ & $\mid x^{n}$ \\
\hline 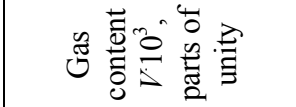 & $\frac{\mathcal{I}}{m}$ & $\begin{array}{l}\stackrel{0}{+} \\
+ \\
+ \\
+\end{array}$ & $\begin{array}{l}n \\
\check{n} \\
n\end{array}$ & हి. & \\
\hline 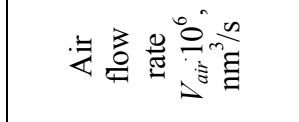 & $\stackrel{\infty}{\stackrel{\infty}{0}}$ & zo & 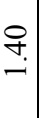 & $\begin{array}{l}\text { ?ִ } \\
\stackrel{n}{\longrightarrow}\end{array}$ & \\
\hline
\end{tabular}


Table 4

The calculated kinetic values for the reaction of dissolved oxygen and reducing form of quinhydrone oligomers

\begin{tabular}{|c|c|c|c|c|c|}
\hline \multirow{2}{*}{$\begin{array}{l}\text { Air flow rate } \\
V_{\text {air }} \cdot 10^{6}, \mathrm{~nm}^{3} / \mathrm{s}\end{array}$} & \multirow{2}{*}{$\begin{array}{c}\text { Oxygen chemisorption rate } \\
v_{\text {chem }} 10^{3}, \\
v_{\text {chem }}=\Delta N /\left(\tau \cdot V_{s}\right), \mathrm{mol} /\left(\mathrm{m}^{3} \cdot \mathrm{s}\right)\end{array}$} & \multicolumn{2}{|c|}{ Reaction rate constants } & \multirow{2}{*}{$\begin{array}{c}\text { Reaction rate } \\
v_{r}=k_{1} \cdot C_{1}{ }^{*} \cdot C_{2}, \mathrm{~mol} /\left(\mathrm{m}^{3} \cdot \mathrm{s}\right)\end{array}$} & \multirow{2}{*}{$\begin{array}{l}\text { Ratio } \\
v_{r} / v_{\text {chem }}\end{array}$} \\
\hline & & $k_{1}, \mathrm{~m}^{3} /(\mathrm{s} \cdot \mathrm{mol})$ & $k_{2}, \mathrm{~s}^{-1}$ & & \\
\hline 0.78 & 1.390 & \multirow{5}{*}{0.1547} & \multirow{5}{*}{17.41} & \multirow{5}{*}{0.593} & 427 \\
\hline 1.05 & 1.546 & & & & 384 \\
\hline 1.40 & 1.736 & & & & 342 \\
\hline 1.56 & 1.852 & & & & 320 \\
\hline 1.83 & 1.905 & & & & 311 \\
\hline
\end{tabular}

\section{Conclusions}

The mass transfer coefficients in gas and liquid phases during oxygen absorption with soda solution were calculated. It is shown that the resistance of the liquid phase is by $(1.9-2.7) \cdot 10^{3}$ times greater than the resistance of the gas phase. The enhancement factor of oxygen absorption during the regeneration of a quinhydrone solution in the apparatus with a continuous bubbling layer was found to be 5.14 , indicating that the chemical reaction between absorbed oxygen and the reducing form of quinhydrone oligomers occurs in a liquid film with a high rate. The rate constant for the reaction of chemisorbed oxygen and the reducing form of quinhydrone oligomers was found to be $0.1547 \mathrm{~m}^{3} /(\mathrm{s} \cdot \mathrm{mol})$. In the apparatus with a continuous bubbling layer, the liquid-side resistance during oxygen absorption is large, which does not provide the necessary rate of quinhydrone solution regeneration. Therefore, this type of mass-transfer equipment can not be recommended for regeneration of absorbing solution used in quinhydrone method of hydrogen sulfide removal from gases.

\section{References}

[1] Yavorskiy V., Slyuzar A., Kalymon Y. Chem. Chem. Technol., 2016, 10, 613. https://doi.org/10.23939/chcht10.04si.613

[2] Menkovsky M., Yavorskiy V.: Technologia Sery. Khimia, Moskva 1985.

[3] Kohl A., Nielsen R.: Gas Purification. Gulf Publ. Co., Houston 1997.

[4] Tarumi M., Matsuzaki Y., Suzuki K.: Chem. Eng. Sci., 2019, 199, 381. https://doi.org/10.1016/j.ces.2019.01.006
[5] Bannikov L., Smirnova A., Nesterenko S.: Chem. Chem. Technol., 2016, 10, 67. https://doi.org/10.23939/chcht10.01.67

[6] Dong Y., Ling K., Zhang W., Luo H.: Adv. Mater. Res., 2001, 233-235, 892. https://doi.org/10.4028/www.scientific.net/AMR.233235.892

[7] Safarzadeh-Amiri A., Zhang Y., El-Din M.: Appl. Catal. B, 2017, 218, 186. https://doi.org/10.1016/j.apcatb.2017.06.040

[8] Yavorskiy V., Slyuzar A., Mertsalo I., Kalymon Ya.: Vopr. Khim. Khim. Tekhnol., 2011, 4, 301.

[9] Ramm V.: Absorptsia Gazov. Khimia, Moskva 1976.

[10] Yavorskiy V., Slyuzar A., Kalymon Ya.: Khim. Prom. Ukrainy, 2011, 1, 26.

[11] Yavorskiy V., Helesh A.: Chem. Chem. Technol., 2015, 9, 471. https://doi.org/10.23939/chcht09.04.471

[12] Kalymon Ya., Znak Z., Helesh A., Savchuk L.: Vopr. Khim. Khim. Tekhnol., 2018, 5, 102.

Received: May 16, 2019 / Revised: June 10, 2019 / Accepted: November 12, 2019

\section{ДОСЛДЖЕННЯ ХЕМОСОРБЦІЇ КИСНЮ ПІД ЧАС РЕГЕНЕРАЦІЇ ХІНГІДРОННОГО ПОГЛИНАЛЬНОГО РОЗЧИНУ В АПАРАТАХ З СУЦІЛЬНИМ БАРБОТАЖНИМ ШАРОМ}

Анотація. Визначено коефіцієнт прискорення абсорбиіі кисню повітря хінгідронним поглинальним розчином в апараті з суиільним барботажним шаром, а також константу швидкості реакиії між хемосорбованим киснем і відновною формою олігомерів хінгідрону. Отримані результати мають практичне значення для вибору масообмінного апарату для регенерації поглинального розчину у хінгідронному методі очищення газів від сірководню.

Ключові слова: хемосорбиія кисню, поглинальний розчин, регенерачія, хінгідрон, олігомери, барботажний шар. 